\title{
Effects of temperature, salinity and clay particles on inactivation and decay of cold-active marine Bacteriophage 9A
}

\author{
Llyd E. Wells ${ }^{1,2, *}$, Jody W. Deming ${ }^{1}$ \\ ${ }^{1}$ School of Oceanography, University of Washington, Box 357940, Seattle, Washington 98195-7940, USA \\ ${ }^{2}$ Present address: Center for Northern Studies, Sterling College, PO Box 72, Craftsbury Common, Vermont 05827, USA
}

\begin{abstract}
The effects of temperature, salinity and clay particles on the inactivation and decay of the cold-active Bacteriophage 9A, isolated from particle-rich Arctic seawater, were examined using a plating technique to evaluate infectivity (inactivation) and epifluorescence microscopy to measure phage concentrations (decay). Phage 9A was rapidly inactivated over a temperature test range of 25 to $55^{\circ} \mathrm{C}$ in marine broth (salinity of $36 \mathrm{psu}$ ), with half-lives ranging from $<10 \mathrm{~min}$ at $25^{\circ} \mathrm{C}$ to $\sim 1 \mathrm{~min}$ at $32.5^{\circ} \mathrm{C}$ and too rapid to measure at $\geq 35^{\circ} \mathrm{C}$, making it among the most thermolabile phages. When salinity was varied at $30^{\circ} \mathrm{C}$, the inactivation rates in brackish (21 psu) and briny (161 psu) broth were indistinguishable from that in marine broth $(p>0.20)$. At the environmentally relevant temperature of $-1^{\circ} \mathrm{C}$, however, loss of infectivity in briny broth was 3 to 4 times greater than in marine or brackish broth. As commonly observed, viral decay determined microscopically often substantially underestimated loss of infectivity: at $30^{\circ} \mathrm{C}$, loss of infectivity exceeded the viral decay rate by approximately 1000 -fold, while at $-1^{\circ} \mathrm{C}$, microscopic counts did not detect any of the losses observed by plaque assay. Under conditions comparable to a winter sea-ice brine inclusion $\left(-12^{\circ} \mathrm{C}\right.$ and $\left.161 \mathrm{psu}\right)$, however, plating and microscopy were in substantive agreement, indicating relatively minor losses of 16 to $34 \%$ losses over a 5 wk period. Illite, kaolinite or montmorillonite clays had no statistically significant effect on phage inactivation as a function of temperature or salinity, although rates tended to be slower in the presence of the clays. In general, our results emphasize the importance of working with cold-active phages under environmentally-relevant conditions of temperature and salinity. They also imply decay processes that involve viral proteins rather than nucleic acids; as a result, affected viruses may be recalcitrant to reactivation by known host-based repair mechanisms.
\end{abstract}

KEY WORDS: Virus $\cdot$ Phage 9A $\cdot$ Colwellia psychrerythraea 34H $\cdot$ Temperature $\cdot$ Salinity $\cdot$ Clay Illite $\cdot$ Mackenzie Shelf

Resale or republication not permitted without written consent of the publisher

\section{INTRODUCTION}

Cold-active viruses (i.e. those capable of infection and production at $\leq 4^{\circ} \mathrm{C}$ ) await systematic study despite the volumetric dominance of the cold ocean. Field investigations in polar environments indicate that viruses can remain active at low temperature (e.g. Maranger et al. 1994, Gowing et al. 2002, Middelboe et al. 2002), with bacterial losses due to viruses sometimes equaling or exceeding those due to grazers (Steward et al. 1996, Guixa-Boixereu et al. 2002, Wells \& Deming 2006b). Virus production has been demon- strated even under conditions characteristic of brine inclusions in winter sea ice $\left(-12^{\circ} \mathrm{C}\right.$ and a salinity of 160 $\mathrm{psu}_{i}$ Wells \& Deming 2006a). High viral concentrations in the deep ocean (e.g. Hara et al. 1996, Weinbauer et al. 2003, Ortmann \& Suttle 2005) also imply viral activity at low temperatures, but in situ or laboratory research pertinent to viral processes there has been rare (Wiebe \& Liston 1968, Weinbauer et al. 2003, Wells \& Deming 2006c, this issue).

Information on the decay of cold-active viruses derives from largely qualitative analyses conducted more than 30 yr ago (reviewed by Wells 2006). These studies 
show that cold-active viruses are typically more thermolabile than viruses not capable of cold activity. While the latter tend to survive long exposure (60 min or greater) at $60^{\circ} \mathrm{C}$ with minimal loss of titer (Olsen et al. 1968), a dramatic reduction in titer of $\geq 99 \%$ is common for cold-active viruses at this or cooler temperatures (reported down to $45^{\circ} \mathrm{C}$ ) within $10 \mathrm{~min}$ (Spencer 1955, 1963, Olsen et al. 1968, Wiebe \& Liston 1968, Kulpa \& Olsen 1971, Whitman \& Marshall 1971, Delisle \& Levin 1972). If associated with greater flexibility in viral proteins, as seen in cold-active enzymes (Feller \& Gerday 2003), this increased lability could be an adaptive trait in environments of low thermal energy, for example, facilitating viral interaction with cell-surface receptor(s) or nucleic acid injection.

By further analogy to cold-active enzymes, we hypothesized that particles or organic material sorbed to particles could stabilize cold-active viruses at low temperature, just as various surfaces (Gianfreda \& Scarfi 1991, Meyer-Reil 1991) and extracellular polymeric substances (Huston et al. 2004) appear to stabilize extracellular enzymes. Several viral studies, although not of cold-active viruses, point to this possibility. Hurst et al. (1989) found that the strongest correlates of the inactivation rate of enteroviruses in freshwater at $1{ }^{\circ} \mathrm{C}$ were turbidity and suspended solid concentration; the correlations were negative, implying a preservative effect. Stotzky et al. (1981) reported that the presence of clays enhanced the lifetimes of different bacterial viruses in Tris buffer at both low $\left(4^{\circ} \mathrm{C}\right)$ and high $\left(37^{\circ} \mathrm{C}\right)$ temperatures, frequently by at least a factor of 2 , depending on the virus and the clay. Survival of Type-1 poliovirus in seawater at $25^{\circ} \mathrm{C}$ was also enhanced in the presence of montmorillonite (tested at very high concentrations of $500 \mathrm{mg} \mathrm{l}^{-1}$ ), from which the virus could desorb and be recovered (Gantzer et al. 1994). In contrast, lower montmorillonite concentrations did not effect poliovirus inactivation in deionized water between 19 and $35^{\circ} \mathrm{C}$ (Quignon \& Schwartzbrod 1995).

While not testing temperature per se, additional work has shown that association with particles (especially clays) can substantially prolong viral survival in seawater (e.g. Bitton \& Mitchell 1974, Smith et al. 1978, LaBelle \& Gerba 1979, 1980, Schaiberger et al. 1982). Most of these studies, as well as those examining temperature effects explicitly, addressed viruses infecting animals or enteric bacteria; the effects of mineralogical or sedimentary particles on indigenous marine viruses have been little studied (in contrast to organic or uncharacterized particles, which appear to enhance decay; Suttle \& Chen 1992, Noble \& Fuhrman 1997). Hewson \& Fuhrman (2003) reported rapid sorptive scavenging of marine viruses by mineralogically uncharacterized suspended sediments, depending on sediment concentration, size and source, but no data regarding infectivity of the sorbed viruses were presented. Carlson et al. (1968) likewise observed sorption of bacteriophage T2 to a natural assemblage of river particles, with sorption enhanced as $\mathrm{CaCl}_{2}$ concentration increased; in the case of additional experiments with kaolinite, sorption was reversible with no loss in titer. The fact that viruses infecting cyanobacteria and Heterosigma akashiwo have been isolated from sediments to depths of 30 to $40 \mathrm{~cm}$, with a corresponding $\mathrm{Pb}^{210}$ age of $\sim 100 \mathrm{yr}$ in one case, also suggests that at least some particles act to preserve viruses in marine environments (Lawrence et al. 2002).

Isolated from an Arctic nepheloid layer, a distinct particle-rich region of the water column often associated with the bottom, and characterized by unprecedented cold activity to at least $-10^{\circ} \mathrm{C}$ (Wells \& Deming 2006c), Phage 9A is an obvious candidate for studies that explore whether, as in enzymes, cold activity is associated with greater lability in viruses and, if so, whether particles offset that lability. For this work, we focused on clay particles, which (along with silts) dominate the particle load of the Mackenzie River (Carson et al. 1998), the major sediment source for the Mackenzie Shelf area (Macdonald et al. 1998), whence 9A was isolated. Two of the clays we chose, kaolinite and illite, are of known regional significance, with illite composing up to $60 \%$ of total clays in the area (Mowatt \& Naidu 1987). We also considered montmorillonite, present regionally only in trace amounts (Emeis 1985, Mowatt \& Naidu 1987) but better evaluated in the microbial literature. Since the site from which 9A was isolated is notable for its wide salinity range, from brackish surface waters due to input from rivers and melting sea ice (see Fig. 2B of Wells et al. 2006) to the brines of winter sea ice, we also considered the effects of salinity on phage decay at both elevated $\left(30^{\circ} \mathrm{C}\right)$ and in situ $\left(-1\right.$ and $\left.-12^{\circ} \mathrm{C}\right)$ temperatures, including in the presence of clays.

\section{MATERIALS AND METHODS}

Media, reagents and viral stock. Most experiments were conducted in 50\% marine broth 2216 (Difco), hereafter called marine broth, prepared by mixing equal volumes of full strength 2216 and artificial seawater (ASW), where ASW is $24 \mathrm{~g} \mathrm{NaCl}, 0.7 \mathrm{~g} \mathrm{KCl}, 5.3 \mathrm{~g} \mathrm{MgCl}_{2} \cdot 6 \mathrm{H}_{2} \mathrm{O}$, and $7 \mathrm{~g} \mathrm{MgSO}_{4} \cdot 7 \mathrm{H}_{2} \mathrm{O}$ in $1 \mathrm{l}$ deionized water. The final salinity was 33 to 34 psu as measured by refractometer. Brackish and briny broths were made as above except that full strength 2216 was diluted in an equal volume of deionized water or $10 \times \mathrm{ASW}$, resulting in measured salinities of $\sim 17$ and $\sim 172 \mathrm{psu}$, respectively. For 1 set of experiments, ASW rather than marine broth was used. In 
this experiment, the ASW was amended with $6 \mathrm{mM}$ $\mathrm{CaCl}_{2} \cdot 2 \mathrm{H}_{2} \mathrm{O}$ and buffered to $\mathrm{pH} 7.5-7.9$ with $1.3 \mathrm{~g} \mathrm{l}^{-1}$ TAPSO(3-[N-tris(hydroxymethyl)methylamino]-2hydroxy-propanesulfonic acid), to correspond to $50 \%$ 2216. All media were pre-filtered $(0.2 \mu \mathrm{m})$ and sterilized by autoclaving.

Clay solutions were prepared using montmorillonite (bentonite clay K-10, Acros Organics), kaolinite (kaolin, Fisher Scientific) or illite (IMt-1, Illite Cambrianshale, Silver Hill, Montana, supplied by the Source Clays Repository, the Clay Minerals Society, Purdue University). The latter was crushed with a mortar and pestle and sieved to remove particles $>125 \mu \mathrm{m}$ in size (the other 2 clays were already powders). In each case, 2 to $5 \mathrm{~g}$ were added to a baked $\left(>100^{\circ} \mathrm{C}\right)$, pre-weighed $250 \mathrm{ml}$ glass bottle (the plastic rim of which had been removed) to which $100 \mathrm{ml}$ of deionized water were added followed by vigorous shaking. The clays were allowed to settle for 80 to 85 min over a $4 \mathrm{~cm}$ pathlength before carefully removing the upper $80 \mathrm{ml}$ as the $\leq 3 \mu \mathrm{m}$ size fraction (calculated by solving for $\chi$ in the Stokes equation: $v=\left(\chi^{2} \cdot g \cdot\left[\rho_{\mathrm{s}}-\rho_{\mathrm{L}}\right]\right) /(18 \cdot \eta)$, where $v$ is the settling velocity ( $4 \mathrm{~cm}$ in 80 to $85 \mathrm{~min}), \chi$ is the estimated spherical diameter, $\rho_{\mathrm{S}}-\rho_{\mathrm{L}}$ is the density difference of solid [clay] and liquid [deionized water] and $\eta$ is the fluid viscosity). The bottle and remaining solution were again baked at $>100^{\circ} \mathrm{C}$ and then weighed; this process was repeated until no further change in mass was observed (i.e. water had evaporated). The difference in weight at the start and end of this procedure enabled calculation of the concentration of clays $\leq 3 \mu \mathrm{m}$ in the distilled water solution, which varied between 1 and $6 \mathrm{mg} \mathrm{ml}^{-1}$ depending on the clay. Clay solutions were autoclaved and aliquots of it added to broth (as above) to achieve a final concentration of $10 \mathrm{mg} \mathrm{l}^{-1}$, which falls within the range of suspended particle concentrations measured in nepheloid layers from the Mackenzie Shelf region (2.2 to $18.4 \mathrm{mg} \mathrm{l}^{-1}$; Wells et al. 2006). The clay-broth solutions were mixed and allowed to equilibrate for a minimum of $1 \mathrm{~d}$ prior to use.

A high titer phage lysate was prepared from silica overlay plates as described by Wells \& Deming (2006c). The phage were stored at $4^{\circ} \mathrm{C}$ in phage buffer: $0.1 \mathrm{M}$ $\mathrm{NaCl}, 50 \mathrm{mM}$ Tris- $\mathrm{HCl} \mathrm{pH}$ 8.0, $8 \mathrm{mM} \mathrm{MgSO}_{4} \cdot 7 \mathrm{H}_{2} 0,2$ $\mathrm{mM} \mathrm{CaCl} 2 \cdot 2 \mathrm{H}_{2} 0,5 \%$ glycerol. As measured by refractometer, the apparent salinity of the phage buffer was $\sim 60 \mathrm{psu}$, much of which was due to the $5 \%$ glycerol (which the refractometer registered as equivalent to 33 to 34 psu salinity).

Experiments on loss of phage infectivity at 25 to $55^{\circ} \mathbf{C}$. To determine the inactivation rate of Phage 9A at temperatures of 25 to $55^{\circ} \mathrm{C}, 900 \mu \mathrm{l}$ of media, with or without clays, were aliquoted into sterile, $1.5 \mathrm{ml}$ microcentrifuge tubes and equilibrated to the experimental temperature in a precision oven for at least $1 \mathrm{~h}$. To start an experiment, $100 \mu$ l of Phage 9A (typically $10^{9}$ to $10^{10}$ phage $\mathrm{ml}^{-1}$ in phage buffer) were added to the media and mixed gently. This addition brought the final salinity to $36 \mathrm{psu}$ (for marine broth or amended ASW), 21 psu (brackish broth) and 161 psu (briny broth); when applicable, it brought the clay concentration to $9 \mathrm{mg} \mathrm{l}^{-1}$. Following mixing and periodically thereafter, $50 \mu \mathrm{l}$ samples were removed to sterile $0.5 \mathrm{ml}$ microcentrifuge tubes on ice. When all samples had been collected (within 15 to $60 \mathrm{~min}$, depending on the temperature), a dilution series of phage was plated using the silica-gel overlay technique (described by Wells \& Deming 2006c) and Colwellia psychrerythraea strain $34 \mathrm{H}$ (henceforth $34 \mathrm{H}$ ) first harvested in mid-exponential growth phase (A600 of 0.2 to 0.3 ) and concentrated 2 to 4 -fold by centrifugation $(6000 \times g$ for $20 \mathrm{~min}$ at $2{ }^{\circ} \mathrm{C}$ ). Plates were incubated at $2^{\circ} \mathrm{C}_{i}$ plaques took approximately $1 \mathrm{wk}$ to form. Inactivation rate constants $(k)$ were calculated as the slope of the linear regression of the natural logarithm of the abundance of plaqueforming units (PFU) against time.

Experiments on loss of phage infectivity at subzero temperatures. As discussed in Wells \& Deming (2006c) and despite efforts to standardize $34 \mathrm{H}$ growth and infection conditions, the efficiency of plating (EOP) of Phage $9 \mathrm{~A}$ on $34 \mathrm{H}$ was highly variable in a way that appears to reflect changing bacterial phenotypes. The exact cause of variability remains unknown. For experiments at temperatures below zero (which required days instead of minutes), variable EOP, rather than loss of infectivity, could account for changes in PFU numbers. To circumvent this ambiguity, a relative (rather than absolute) loss rate was determined as follows: triplicate $900 \mu$ aliquots of marine, brackish or briny broth, with or without illite, were equilibrated for several hours to the experimental temperature before addition of $100 \mu \mathrm{l}$ 9A. After gentle mixing, $5 \mu \mathrm{l}$ were removed and diluted into $0.5 \mathrm{ml}$ of ice-cold marine broth in a sterile microcentrifuge tube. This subsample was kept at $-1^{\circ} \mathrm{C}$ until a second time point was sampled $3 \mathrm{wk}$ later. The 2 time points were then plated as above on the same $34 \mathrm{H}$ stock to determine survival fractions relative to that in $-1{ }^{\circ} \mathrm{C}$ marine broth.

A similar experiment was performed at $-12^{\circ} \mathrm{C}$ in briny broth, since its salinity of 161 psu corresponded to the expected salinity of brine inclusions in sea ice at this temperature ( 158 psu). A $900 \mu \mathrm{l}$ sample of briny broth was equilibrated to $-12^{\circ} \mathrm{C}$ for $6 \mathrm{~h}$ before addition of $100 \mu \mathrm{l}$ Phage 9A as above, followed by gentle mixing. Subsamples of 50 to $100 \mu \mathrm{l}$ for microscopic enumeration of phage (see next subsection) were taken and processed immediately after $0,7,18,36$ and $42 \mathrm{~d}$. Subsamples for PFU were also collected after 7, 18 and $42 \mathrm{~d}$ by diluting $5 \mu \mathrm{l}$ of sample into $0.5 \mathrm{ml}$ of ice-cold marine broth. The $t=7 \mathrm{~d}$ diluted sample was then 
stored at $-1^{\circ} \mathrm{C}$ for $11 \mathrm{~d}$ in order to plate it against the same $34 \mathrm{H}$ stock as the $t=18 \mathrm{~d}$ sample and determine survival fraction as above. Likewise, at the end of the experiment, the stored $t=7$ and $18 \mathrm{~d}$ samples were replated with the $t=42 \mathrm{~d}$ sample. Between Days 36 and 42 , the incubator warmed to $-7^{\circ} \mathrm{C}$.

Microscopic evaluation of phage decay. For a subset of experiments at $-12,-1$ and $30^{\circ} \mathrm{C}$, besides measuring loss of infectivity by plaque assay, changes in phage abundance were monitored by direct counts using SYBR gold staining and epifluorescence microscopy. Sample volumes of 5 to $50 \mu \mathrm{l}$ were fixed in cold ASW amended with formaldehyde $(1.5 \%$ final concentration), and processed to slide stage using a procedure modified from Noble and Fuhrman (1998) as described in Wells \& Deming (2006c). Slides were usually counted immediately and always within $24 \mathrm{~h}$, being stored at $-20^{\circ} \mathrm{C}$ in the interim.

Adsorption of Phage 9A to illite at $-1^{\circ} \mathrm{C}$. To determine whether Phage 9A adsorbed to illite (the most environmentally relevant clay) in brackish, briny or marine broth, triplicate microcentrifuge tubes containing $900 \mu \mathrm{l}$ of cold medium with $10 \mathrm{mg} \mathrm{l}^{-1}$ illite (prepared as described above) were inoculated with $100 \mu \mathrm{l}$ Phage 9A and mixed gently. A subsample of $100 \mu \mathrm{l}$ was removed and diluted in $900 \mu \mathrm{l}$ of the same medium (i.e. brackish, briny or marine) but without illite. The diluted samples were immediately centrifuged for 4 min at $15600 \times g$ in a table-top centrifuge at room temperature to pellet clay and adsorbed viruses; $500 \mu \mathrm{l}$ of overlying supernatant were then fixed in cold ASW containing $1.5 \%$ formaldehyde. A second sample was taken and prepared as above after $2 \mathrm{~h}$. All samples were stained with SYBR gold and viewed by epifluorescence microscopy (as above).

\section{RESULTS}

\section{Effects of temperature, salinity and clays on Phage 9A inactivation and decay at 25 to $55^{\circ} \mathrm{C}$}

As determined by plaque assay, Phage 9A was rapidly inactivated at temperatures between 25 and $32.5^{\circ} \mathrm{C}$ in marine broth, with half-lives declining from 7 to $10 \mathrm{~min}$ at $25^{\circ} \mathrm{C}$ to $\sim 1 \mathrm{~min}$ at $32.5^{\circ} \mathrm{C}$ (Fig. 1). At higher temperatures $\left(35\right.$ to $55^{\circ} \mathrm{C}$ ), rates were too fast to determine accurately. Over the range of 25 to $32.5^{\circ} \mathrm{C}$, phage inactivation rate constants declined linearly with increasing temperature in clay-free controls and all treatments (Table 1). While inactivation rates tended to be

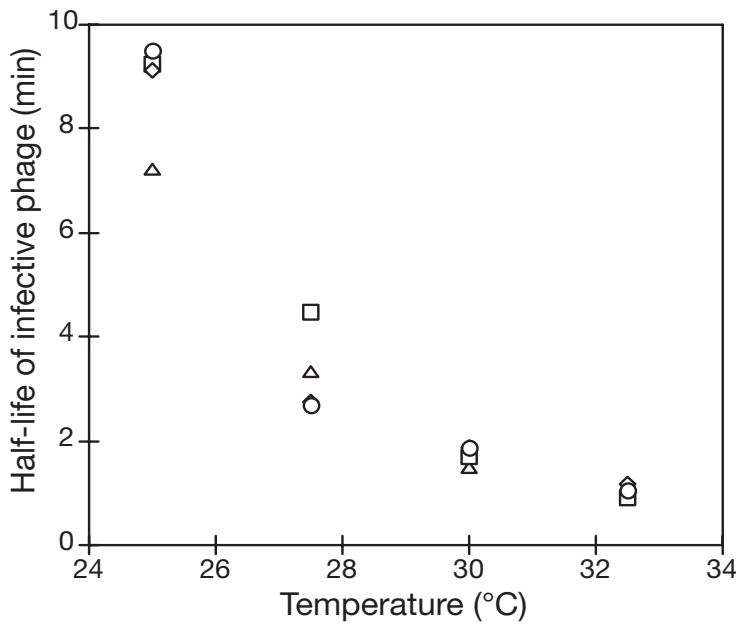

Fig. 1. Phage 9A. Effect of temperature on the half-life of infective phage (determined by plaque assay) in standard marine broth $(\Delta)$ or marine broth amended with $9 \mathrm{mg} \mathrm{l}^{-1}$ montmorillonite $(\square)$, kaolinite $(\diamond)$ or illite $(O)$. See Table 1 for rate constants and their confidence limits

Table 1. Phage 9A. Inactivation rate constants $\left(k, \mathrm{~min}^{-1}\right)$ determined by plaque assay for Phage 9A incubated in marine broth with or without $9 \mathrm{mg} \mathrm{l}^{-1}$ clay; $95 \%$ confidence intervals in parentheses. $\mathrm{p}<0.05$ unless otherwise indicated; ${ }^{*}: \mathrm{p}<0.01^{*}{ }^{* *}: \mathrm{p}<0.001$. Significant $(p<0.05)$ regressions of $k$ against temperature $\left(T,{ }^{\circ} \mathrm{C}\right)$ are given. Significance of linear regressions against time (to determine $k$ ) or temperature was tested by ANOVA

\begin{tabular}{|c|c|c|c|c|c|}
\hline $\begin{array}{l}\text { Temperature } \\
\left({ }^{\circ} \mathrm{C}\right)\end{array}$ & $\begin{array}{l}\text { Incubation } \\
\text { period (min) }\end{array}$ & No addition & Montmorillonite & Kaolinite & Illite \\
\hline 25.0 & 60 & $\begin{array}{c}-0.096^{* *} \\
(-0.103 \text { to }-0.089)\end{array}$ & $\begin{array}{c}-0.075^{*} \\
(-0.107 \text { to }-0.043)\end{array}$ & $\begin{array}{c}-0.076^{*} \\
(-0.103 \text { to }-0.050)\end{array}$ & $\begin{array}{c}-0.073^{* *} \\
(-0.079 \text { to }-0.066)\end{array}$ \\
\hline 27.5 & 40 & $\begin{array}{c}-0.208^{*} \\
(-0.224 \text { to }-0.191)\end{array}$ & $\begin{array}{c}-0.155^{\mathrm{a}} \\
(-0.486 \text { to } 0.176)\end{array}$ & $\begin{array}{c}-0.252^{*} \\
(-0.308 \text { to }-0.196)\end{array}$ & $\begin{array}{c}-0.259 \\
(-0.409 \text { to }-0.109)\end{array}$ \\
\hline 30.0 & 15 or $20^{\mathrm{b}}$ & $\begin{array}{c}-0.466^{*} \\
(-0.548 \text { to }-0.384)\end{array}$ & $\begin{array}{c}-0.411^{*} \\
(-0.625 \text { to }-0.198)\end{array}$ & $\begin{array}{c}-0.370^{*} \\
(-0.535 \text { to }-0.205)\end{array}$ & $\begin{array}{c}-0.370^{* *} \\
(-0.423 \text { to }-0.316)\end{array}$ \\
\hline 32.5 & 15 & $\begin{array}{c}-0.696 \\
(-1.13 \text { to }-0.261)\end{array}$ & $\begin{array}{c}-0.774^{*} \\
(-0.971 \text { to }-0.576)\end{array}$ & $\begin{array}{c}-0.596 \\
(-0.864 \text { to }-0.329)\end{array}$ & $\begin{array}{c}-0.662^{*} \\
(-0.904 \text { to }-0.421)\end{array}$ \\
\hline \multicolumn{2}{|c|}{ Regression equations: } & $-0.082 \times T+2.00$ & $-0.094 \times T+2.35$ & $-0.067 \times T+1.61$ & $-0.075 \times T+1.82$ \\
\hline
\end{tabular}


slower if clays were present, especially at the lowest temperature $\left(25^{\circ} \mathrm{C}\right.$ Fig. 1$)$, rates were not statistically different between treatments (2-factor ANOVA without replication, $p>0.71$ for presence or absence of the specific clay), as also implied by overlap of $95 \%$ confidence intervals (Table 1). Triplicate independent experiments at $30^{\circ} \mathrm{C}$ with or without illite determined slower inactivation rates in the presence of illite $(k \pm \mathrm{SE}$ of the mean: $-0.351 \pm 0.043 \mathrm{~min}^{-1}$ vs. $-0.416 \pm 0.059 \mathrm{~min}^{-1}$ when illite was absent) but the difference was not statistically significant (1-factor ANOVA, $\mathrm{p}>0.45$ ). Illite had no effect on inactivation rates at $27.5^{\circ} \mathrm{C}$ in $\mathrm{CaCl}_{2}$-amended ASW ( $k=-0.164$ and $-0.162 \mathrm{~min}^{-1}$ for the control and illite treatments, respectively); these rates did not differ significantly from those measured in marine broth at this temperature (2-tailed $t$-test, $0.05<\mathrm{p}<0.10)$.

A comparison of inactivation rate constants determined by plaque assay at $30^{\circ} \mathrm{C}$ in broths of differing salinities, with or without illite (Table 2 and Fig. 2), revealed that inactivation tended to be more rapid in briny broth and, at all salinities, if no clay were present. Treatments were not statistically different, however, whether in terms of salinity or the presence or absence of illite (2-factor ANOVA without replication, $p>0.20$ for salinity and $p>0.10$ for illite).

As for direct counts of phage at $30^{\circ} \mathrm{C}$, no decline in number was detected in marine broth over a $15 \mathrm{~min}$ period ( $p>0.92$ for the slope of the regression against time; Fig. 2). The decline over a $24 \mathrm{~h}$ period was significant, however, yielding a decay constant of $-0.025 \mathrm{~h}^{-1}$ (or $-0.0004 \mathrm{~min}^{-1}, \mathrm{p}<0.05$ ), approximately 3 orders of magnitude smaller than that observed when measuring loss of infectivity.

\section{Phage 9A inactivation and decay at subzero temperatures}

After incubation for $3 \mathrm{wk}$ at $-1^{\circ} \mathrm{C}$, the relative survival fractions of infective viruses indicated only small $( \pm 20 \%)$ changes in brackish and marine broth, whether or not illite was present (Fig. 3). In contrast, the fraction fell to $34 \%$ of the initial value in briny broth, with a substantial but smaller decline in the presence of illite (to $61 \%$ of the initial value; Fig. 3). A 2 -factor ANOVA determined that phage survival fractions differed significantly among the salinity treatments $(p<0.005)$ but not among the clay treatments $(p>0.57)$; interactions between salinity and clay treatments were not significant $(p>0.67)$. Accordingly, a post-hoc multiple comparison using the Tukey test was performed to ascertain the source of difference among salinity treatments. Relative survival fractions in briny broth were significantly lower than those in marine broth $(p<0.005)$ but were not different from those in
Table 2. Phage 9A. Inactivation rate constants $\left(k, \mathrm{~min}^{-1}\right)$ for phage incubated at $30^{\circ} \mathrm{C}$ in brackish, briny or marine broth with or without $9 \mathrm{mg} \mathrm{l}^{-1}$ illite. $95 \%$ confidence intervals in parentheses. $\mathrm{p}<0.05$ unless otherwise indicated; $^{*}: \mathrm{p}<0.01$; significance tested by ANOVA

\begin{tabular}{|lcc|}
\hline Salinity (psu) & No addition & Illite \\
\hline 21 & $-0.495^{*}$ & $-0.275^{*}$ \\
& $(-0.639$ to -0.351$)$ & $(-0.366$ to -0.184$)$ \\
36 & $-0.482^{*}$ & $-0.269^{*}$ \\
& $(-0.680$ to -0.283$)$ & $(-0.355$ to -0.182$)$ \\
161 & $-0.565^{\mathrm{a}}$ & -0.540 \\
& $(-1.61$ to 0.482$)$ & $(-0.810$ to -0.270$)$ \\
${ }^{\mathrm{a}} \mathrm{p}<0.10$ & & \\
\hline
\end{tabular}

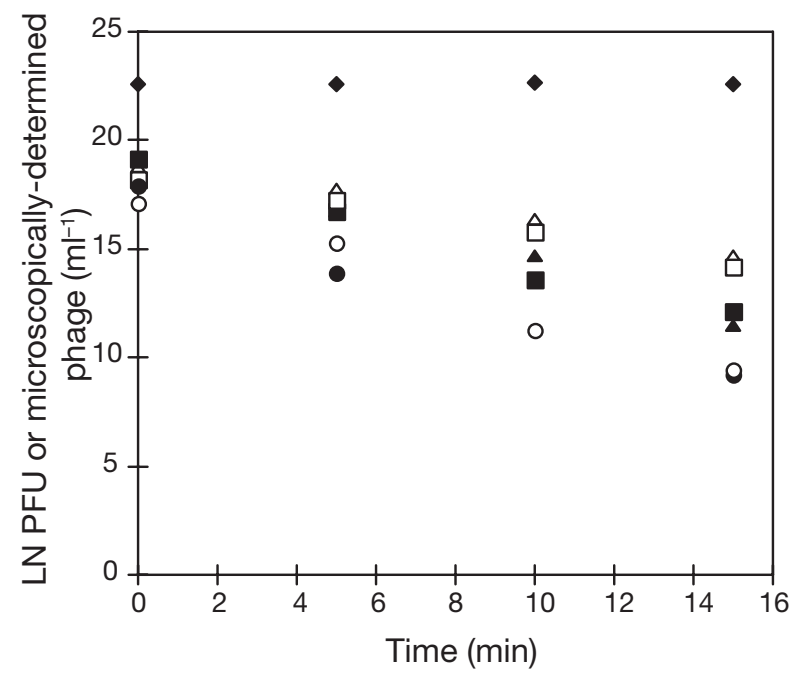

Fig. 2. Phage 9A. Inactivation at $30^{\circ} \mathrm{C}$ in broth of 21,36 or 161 psu, with or without $9 \mathrm{mg} \mathrm{l}^{-1}$ illite. Triangles (21 psu), squares (36 psu) and circles (161 psu): data determined from plaque assay, in the absence (closed symbols) or presence (open symbols) of illite. Diamonds (36 psu): data determined by microscopic count of viruses in a separate experiment

brackish broth $(0.05<\mathrm{p}<0.10)$; survival fractions in brackish and marine broth could not be distinguished statistically $(0.20<\mathrm{p}<0.50)$. A corresponding experiment using epifluorescence microscopy did not detect phage decay at $-1^{\circ} \mathrm{C}$ in any of the 3 broths after $3 \mathrm{wk}$ incubation: the mean recovery percentage in triplicate samples at each salinity was $93 \pm 3,92 \pm 7$ and $101 \pm$ $5 \%$ for brackish, marine and briny broths, respectively.

Finally, as determined by direct microscopic counts, no phage decay occurred in briny broth at $-12^{\circ} \mathrm{C}$ ( $p>0.13$ for the regression over the $42 \mathrm{~d}$ incubation, sampled weekly; $p>0.21$ if limited to the first $36 \mathrm{~d}$, after which the incubator warmed to $-7^{\circ} \mathrm{C}$ ), although the concentrations had declined to $70-80 \%$ of initial 


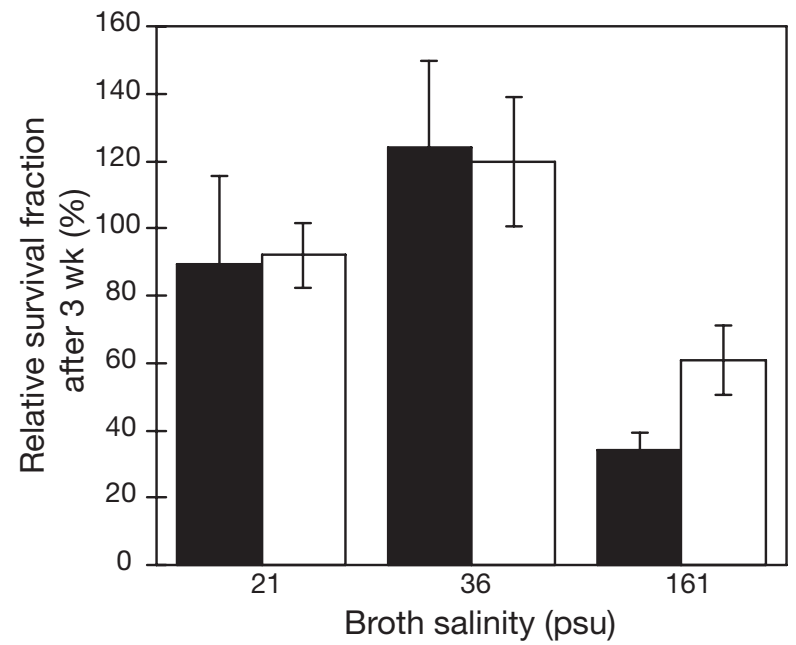

Fig. 3. Phage 9A. Inactivation (relative to that in $-1^{\circ} \mathrm{C}$ marine broth) by plaque assay after $3 \mathrm{wk}$ of incubation at $-1^{\circ} \mathrm{C}$ in broth of 21,36 or $161 \mathrm{psu}$, with (open bars) or without (black bars) $9 \mathrm{mg} \mathrm{l}^{-1}$ illite. Data are averages of independent triplicate experiments, with the standard error of the mean indicated

values by Days 36 or 42 . As regards loss of infectivity over time (relative to that in $-1^{\circ} \mathrm{C}$ marine broth), only fairly minor differences were observed between PFU counts for samples at $t=7 \mathrm{~d}$ and $t=18 \mathrm{~d}$, whether plated on Days 18 or 42 ; the sample at $t=42 \mathrm{~d}$ had 16 to $34 \%$ fewer PFU than the samples at the other 2 time points (Table 3).

\section{Adsorption of Phage 9A to illite at $-1^{\circ} \mathrm{C}$}

Adsorption of Phage 9A to illite was negligible regardless of salinity. The mean percentages of unadsorbed viruses after $2 \mathrm{~h}( \pm \mathrm{SE}$ of the mean, $\mathrm{N}=3)$ were $97 \pm 5,97 \pm 3$ and $98 \pm 5 \%$, for brackish, marine and briny broths, respectively.

Table 3. Phage A. Effect of incubation for 7, 18 or $42 \mathrm{~d}$ at $-12^{\circ} \mathrm{C}$ in briny broth on number of PFU, determined by plating after 18 or $42 \mathrm{~d}$. tntc: too numerous to count

\begin{tabular}{lcccccc}
\multirow{2}{*}{ Dilution } & \multicolumn{3}{c}{ Plated after $18 \mathrm{~d}^{\mathrm{a}}-$} & \multicolumn{2}{c}{ Plated after $42 \mathrm{~d}^{\mathrm{a}}$} \\
& \multicolumn{2}{c}{$t=7 \mathrm{~d}$} & $t=18 \mathrm{~d}$ & $t=7 \mathrm{~d}$ & $t=18 \mathrm{~d}$ & $t=42 \mathrm{~d}^{\mathrm{b}}$ \\
\hline $1: 10^{5}$ & tntc & tntc & 308 & 338 & 259 \\
$1: 10^{6}$ & 125 & 124 & 40 & 50 & 33 \\
$1: 10^{7}$ & 16 & 11 & - & - & -
\end{tabular}

${ }^{a}$ Because of the variable EOP, viruses sampled on different days were plated on same host stock by storing viruses in the interim in $-1^{\circ} \mathrm{C}$ marine broth; inactivation in $-12^{\circ} \mathrm{C}$ briny broth is thus relative to that in $-1^{\circ} \mathrm{C}$ marine broth (see 'Materials and methods' for further details)

${ }^{\mathrm{b}}$ Incubator warmed to $-7^{\circ} \mathrm{C}$ between Days 36 and 42

\section{DISCUSSION}

As with other known cold-active viruses, Phage 9A is extremely sensitive to temperatures readily tolerated by other viruses, being among the most thermolabile of bacteriophages yet described. The linear regression against temperature (Table 1) implies that 1.5 to $3 \mathrm{~min}$ would suffice to reduce $9 \mathrm{~A}$ titers to $1 \%$ of initial values at temperatures between 45 and $60^{\circ} \mathrm{C}$ (the temperature range in which other studies have been conducted), comparable to reported characteristics of cold-active Phages P/14 and P/SW1/b (Spencer 1963), $\mathrm{ps}_{1}$ (Whitman \& Marshall 1971), 23 and 27 (Delisle \& Levin 1972) and an unnamed Aeromonas phage (Wiebe \& Liston 1968) in this temperature range. The use of different media for determining inactivation rates, usually only at a single temperature, constrains rigorous comparison, however, since medium composition, including cation and organic concentrations, affects thermal inactivation of viruses, including coldactive viruses (Spencer 1955, 1963). At least among variables that we considered, such effects were minor for 9A, as indicated by the statistically indistinguishable rate constants determined in amended ASW (at $27.5^{\circ} \mathrm{C}$ ), brackish or briny broth (at $30^{\circ} \mathrm{C}$; Fig. 2) and in the presence of various clays (at 25 to $32.5^{\circ} \mathrm{C}$; Table 1) when compared to the corresponding rate constants in marine broth.

At a temperature of $25^{\circ} \mathrm{C}$, commonly used for laboratory work with viruses, inactivation of Phage 9A was still several orders of magnitude faster $\left(-0.096 \mathrm{~min}^{-1}\right)$ than reported for other (non-cold-active) marine phage at 23 to $25^{\circ} \mathrm{C}$ (undetectable to $-0.0002 \mathrm{~min}^{-1}$ in $0.2 \mu \mathrm{m}$ filtered seawater incubated without sunlight; Suttle \& Chen 1992) as well as non-native viruses in seawater at these temperatures (Kapuscinski \& Mitchell 1980). Below $24^{\circ} \mathrm{C}$, unrealistic inactivation rate constants $(\geq 0)$ predicted from the linear regression of $k$ versus temperature suggest that, at lower temperatures, thermal inactivation of 9A proceeds much more slowly and possibly by a different mechanism than at higher temperatures. In contrast to loss of infectivity, microscopically-determined decay of $9 \mathrm{~A}$ at $30^{\circ} \mathrm{C}\left(-0.025 \mathrm{~h}^{-1}\right)$ was comparable to values reported in other studies at mesophilic temperatures: e.g. -0.016 to $-0.031 \mathrm{~h}^{-1}$ at $18^{\circ} \mathrm{C}$ in Chesapeake Bay estuarine waters (Wommack et al. 1996); and -0.009 to $-0.025 \mathrm{~h}^{-1}$ at summer temperatures (not specified) in Gulf of Mexico surface waters (Wilhelm et al. 1998a). These studies also emphasized the discordance between loss of infectivity and phage decay, as discussed earlier by Suttle \& Chen (1992). While the loss of infectivity in Gulf of Mexico waters was 40 times greater than the decay rate of viral particles (Wilhelm et al. 1998a), for Phage $9 \mathrm{~A}$ at $30^{\circ} \mathrm{C}$ it was approximately 1000 times greater (Fig. 2). A less 
dramatic disjunction was also observed in briny broth at $-1^{\circ} \mathrm{C}$ (Fig. 3). These results add to the importance of distinguishing loss of infectivity from phage decay determined by direct counts: at least under some circumstances, large fractions of microscopically observed viruses in cold waters and in sea ice may not be infectious.

The exact mechanism by which temperature affects phage inactivation is not clear; for example, some authors have suggested that it merely modulates other inactivation mechanisms (Kapuscinksi \& Mitchell 1980). Our experimental conditions ruled out other common causes of inactivation (Suttle \& Chen 1992, Wommack et al. 1996, Noble \& Fuhrman 1997, Weinbauer et al. 1999), including sunlight, biological activity (the solutions were sterile) and adsorption to particles (the solutions were $0.2 \mu \mathrm{m}$-filtered, and added clays had no significant effect). Nor is there evidence that the nucleic acids of cold-active viruses are more thermolabile than those of other viruses or organisms; the only available data do not indicate a pronounced difference (Chen et al. 1966). Instead, the enhanced thermal sensitivity of these viruses may be due to structural changes in the virion, potentially involving proteins or enzymes utilized for host recognition, attachment or DNA injection. An important ecological implication is that, in contrast to loss of infectivity due to largely reversible UV-associated nucleic acid damage (Wilhelm et al. 1998b), loss of infectivity due to protein lability may prevent infection altogether and be irreversible. In general, this suggests that decay processes affecting viral nucleic acids should be distinguished from those affecting viral proteins, especially given known mechanisms of repair only for the former and the likelihood that light-mediated nucleic acid damage does not pertain to large volumes of the ocean.

Because of the variable EOP of the 9A-34H PHS (for detailed discussion, see Wells \& Deming 2006c) and the long incubation periods required for meaningful measurements at low temperature, we were unable to estimate an absolute inactivation rate at $-1^{\circ} \mathrm{C}$. The viability of stocks at $4^{\circ} \mathrm{C}$ for $>6$ mo in phage buffer, with minimal loss of titer determined epifluorescently and only the expected range of vacillations (due to the variable EOP) measured by plating, argue that 9A is stable for long periods of time at low temperature. In support of this, no significant decline in phage was observed microscopically over a $3 \mathrm{wk}$ period at $-1^{\circ} \mathrm{C}$, either in normal, brackish or briny broths. Likewise, the relative survival fractions in marine and brackish broths over this time period varied only by $\pm 20 \%$ (Fig. 3 ), which is within the accuracy of our plaque-counting method. These results do not preclude some loss of infectivity, however, since the experiments were normalized to $-1^{\circ} \mathrm{C}$ marine broth, in which the absolute inactivation rate is unknown. The relative decline in briny broth also serves as a reminder that direct counts may underestimate loss of infectivity, as discussed above.

While salinity-temperature couples of 21 or $36 \mathrm{psu}$ and $-1^{\circ} \mathrm{C}$ are environmentally relevant in the Arctic region where Phage 9A was isolated, it is unlikely that Phage 9A would experience 161 psu salinity except at much lower temperatures characterizing winter seaice brine inclusions. Since previous work has shown that concentrations of winter sea-ice viruses persist or increase over prolonged (8 d) incubations with co-occurring bacteria in 160 psu brine at $-12{ }^{\circ} \mathrm{C}$ (the environmentally-relevant temperature; Wells \& Deming 2006a), we investigated inactivation of Phage 9A at this salinity and temperature in a sterile solution relative to that in marine broth at $-1^{\circ} \mathrm{C}$. Over a $5 \mathrm{wk}$ period, the number of both phage and PFU decreased by only 16 to $34 \%$ (Table 3), much less than the decrease in PFU observed at $-1^{\circ} \mathrm{C}$ in briny broth over $3 \mathrm{wk}(66 \%$; Fig. 3). Thus, consistent with our previously reported field results, these data support possible long-term persistence, if not activity, of viruses in the extreme brines and low temperatures of winter sea ice, although other loss factors in natural brines (for example, instability after precipitation of a specific salt or degradation by cells or extracellular enzymes) require further consideration.

Finally, contrary to our hypothesis, none of the examined clays significantly enhanced the stability of Phage 9A either as a function of temperature or salinity, despite the tendency for the inactivation rates to be lower in the presence of clays (Figs. $1 \& 3$ and Tables 2 $\& 3)$. Consistent with this conclusion, we found no evidence at any of the salinities tested that Phage 9A adsorbed to illite, the best-represented clay along the Mackenzie Shelf. Using an experimental approach basically the same as that detailed here, but in a freshwater system, Carlson et al. (1968) measured considerable adsorption (typically $>80 \%$ ) of T2 to illite, kaolinite or montmorillonite, with greater adsorption observed at increasing $\mathrm{NaCl}$ concentrations. They used higher concentrations of clay $\left(50 \mathrm{mg} \mathrm{l}^{-1}\right)$ than in our experiments, however, as also in another study reporting significant effects of clays on viruses (Gantzer et al. 1994). Such concentrations of suspended matter are only occasionally observed in the Mackenzie Shelf region (Hill \& Nadeau 1989, Wells et al. 2006). A potential confounder in our experiments was the high concentration of organic matter in the broths we used, as both Carlson et al. (1968) and Stotzky et al. (1981) reported that organics could inhibit phage adsorption to clays, presumably by outcompeting phage for binding sites. On the other hand, organics did not affect adsorption of enteric viruses to sediments in the experiments of LaBelle \& Gerba (1979) and are inevitably 
present environmentally. That we saw no statistical difference between inactivation rate constants in marine broth or ASW (with or without illite) argues against the importance of this possible confounder. Instead, our data indicate that the clays we considered had little effect (either preservative or deleterious) on 9A, although we caution against indiscriminately extending these results to the diverse assemblages of particles and viruses found in situ. We also note that viruses not adsorbing to particles and thus possibly avoiding removal from the water column may be selectively favored, perhaps especially if their hosts are free-living.

\section{CONCLUSIONS}

Like the few other cold-active viruses examined to date, Phage 9A is extremely thermolabile, a fact that argues that considerable care should be taken to isolate and study cold-active viruses at low temperatures. In the range of 25 to $32.5^{\circ} \mathrm{C}$, where infectivity was readily quantifiable, this lability was not affected by salinity or clay particles. At $-1^{\circ} \mathrm{C}$, relative inactivation was negligible over a $3 \mathrm{wk}$ period except in high salinity (161 psu) broth. In the same briny solution dropped to $-12{ }^{\circ} \mathrm{C}$, minor viral losses pointed to the possible persistence of phage in winter sea-ice brine inclusions on seasonal and possibly multi-year timescales. Future work could profitably examine the structural basis of thermolability in 9A, explore the proteomes of this and other cold-active phage for proteins and enzymes specifically adapted to operation at near-zero temperatures, and systematically investigate whether phage survival and persistence are optimized to the temperature range of their in situ environments.

Acknowledgements. We thank S. Carpenter for assistance, J. Baross for discussion, 3 anonymous reviewers for substantive comments that improved an earlier version of this manuscript, and R. Sirius, S. Redding and D. Moore. This work is a contribution to the international Canadian Arctic Shelf Exchange Study (CASES) and was funded by the UW Astrobiology Program through NSF-IGERT (DGE-9870713) and NASA-ABI (NCC 2-1273) awards.

\section{LITERATURE CITED}

Bitton G, Mitchell R (1974) Effects of colloids on the survival of bacteriophages in seawater. Water Res 8:227-229

Carlson GF Jr, Woodard FE, Wentworth DF, Sproul OJ (1968) Virus inactivation on clay particles in natural waters. J Water Pollut Control Fed 40:R89-R106

Carson MA, Jasper JN, Conly FM (1998) Magnitude and sources of sediment input to the Mackenzie Delta, Northwest Territories, 1974-94. Arctic 51:116-124

Chen PK, Citarella RV, Salazar O, Colwell RR (1966) Properties of two marine bacteriophages. J Bacteriol 91:1136-1139
Delisle AL, Levin RE (1972) Characteristics of three phages infectious for psychrophilic fishery isolates of Pseudomonas putrefaciens. Antonie Leeuwenhoek 38:1-8

Emeis K (1985) Particulate suspended matter in major world rivers. II. Results on the rivers Indus, Waikato, Nile, St. Lawrence, Yangtse, Parana, Orinoco, Caroni and Mackenzie. Mitt Geol-Paläont Inst Univ Hamburg 58:593-617

Feller G, Gerday C (2003) Psychrophilic enzymes: hot topics in cold adaptation. Nature Rev Microbiol 1:200-208

Gantzer C, Quignon F, Schwartzbrod (1994) Poliovirus-1 adsorption onto and desorption from montmorillonite in seawater: survival of the adsorbed virus. Environ Technol 15:271-278

Gianfreda L, Scarfi MR (1991) Enzyme stabilization: state of the art. Mol Cell Biochem 100:97-128

Gowing MM, Riggs BE, Garrison DL, Gibson AH, Jeffries MO (2002) Large viruses in Ross Sea late autumn pack ice habitats. Mar Ecol Prog Ser 241:1-11

Guixa-Boixereu N, Vaque D, Gasol JM, Sanchez-Camara J, Pedros-Alio C (2002) Viral distribution and activity in Antarctic waters. Deep-Sea Res II 49:827-845

Hara S, Koike I, Terauchi K, Kamiya H, Tanoue E (1996) Abundance of viruses in deep oceanic waters. Mar Ecol Prog Ser 145:269-277

Hewson I, Fuhrman JA (2003) Viriobenthos production and virioplankton sorptive scavenging by suspended sediment particles in coastal and pelagic waters. Microb Ecol 46: $337-347$

Hill PR, Nadeau OC (1989) Storm-dominated sedimentation on the inner shelf of the Canadian Beaufort Sea. J Sediment Petrol 59:455-468

Hurst CJ, Benton WH, McClellan KA (1989) Thermal and water source effects upon the stability of enteroviruses in surface freshwaters. Can J Microbiol 35:474-480

Huston AL, Methé B, Deming JW (2004) Purification, characterization and sequencing of an extracellular cold-active aminopeptidase produced by marine psychrophile Colwellia psychrerythraea strain $34 \mathrm{H}$. Appl Environ Microbiol 70:3321-3328

Kapuscinski RB, Mitchell R (1980) Processes controlling virus inactivation in coastal waters. Water Res 14:363-371

Kulpa CF, Olsen RH (1971) Properties of psychrophilic bacteriophage specific for Micromonas cryophilus. Can J Microbiol 17:157-160

LaBelle RL, Gerba CP (1979) Influence of pH, salinity and organic matter on the adsorption of enteric viruses to estuarine sediment. Appl Environ Microbiol 38:93-101

LaBelle RL, Gerba CP (1980) Influence of estuarine sediment on virus survival under field conditions. Appl Environ Microbiol 39:749-755

Lawrence JE, Chan AM, Suttle CA (2002) Viruses causing lysis of the toxic bloom-forming alga Heterosigma akashiwo (Raphidophyceae) are widespread in coastal sediments of British Columbia, Canada. Limnol Oceanogr 47:545-550

Macdonald RW, Solomon SM, Cranston RE, Welch HE, Yunker MB, Gobeil C (1998) A sediment and organic carbon budget for the Canadian Beaufort Sea. Mar Geol 144: 255-273

Maranger R, Bird DF, Juniper SK (1994) Viral and bacterial dynamics in Arctic sea ice during the spring algal bloom near Resolute, NWT, Canada. Mar Ecol Prog Ser 111: 121-127

Meyer-Reil LA (1991) Ecological aspects of enzyme activity in marine sediments. In: Chrost RJ (ed) Microbial enzymes in aquatic environments. Springer-Verlag, New York, p 84-95

Middelboe M, Nielsen TG, Bjørnsen PK (2002) Virus and bac- 
terial production in the North Water: in situ measurements, batch-culture experiments and characterization and distribution of a virus-host system. Deep-Sea Res II 49:5063-5079

Mowatt TC, Naidu AS (1987) A brief overview of the clay mineral assemblages in sediments of the major rivers of Alaska and adjacent Arctic Canada. Mitt Geol-Paläont Inst Univ Hamburg 64:269-277

Noble RT, Fuhrman JA (1997) Virus decay and its causes in coastal waters. Appl Environ Microbiol 63:77-83

Noble RT, Fuhrman JA (1998) Use of SYBR Green I for rapid epifluorescence counts of marine viruses and bacteria. Aquat Microb Ecol 14:113-118

Olsen RH, Metcalf ES, Todd JK (1968) Characteristics of bacteriophages attacking psychrophilic and mesophilic pseudomonads. J Virol 2:357-364

Ortmann AC, Suttle CA (2005) High abundances of viruses in a deep-sea hydrothermal vent system indicates viral mediated microbial mortality. Deep-Sea Res I 52:1515-1527

Quignon F, Schwartzbrod L (1995) Influence of salts and montmorillonite upon heat inactivation of poliovirus in sterile water. Water Sci Technol 31:177-180

Schaiberger GE, Edmond TD, Gerba CP (1982) Distribution of enterovirus in sediments contiguous with a deep marine sewage outfall. Water Res 16:1425-1428

Smith EM, Gerba CP, Melnick JL (1978) Role of sediment in the persistence of enteroviruses in the estuarine environment. Appl Environ Microbiol 35:685-689

Spencer R (1955) A marine bacteriophage. Nature 175:690-691

Spencer R (1963) Bacterial viruses in the sea. In: Oppenheimer $\mathrm{CH}$ (ed) Symposium on marine microbiology. Charles C. Thomas, Springfield, IL, p 350-365

Steward GF, Smith DC, Azam F (1996) Abundance and distribution of bacteria and viruses in the Bering and Chukchi Seas. Mar Ecol Prog Ser 131:287-300

Stotzky G, Schiffenbauer M, Lipson SM, Yu BH (1981) Surface interactions between viruses and clay minerals and microbes: mechanisms and implications. In: Goddard M, Butler M (eds) Viruses and wastewater treatment. Pergamon Press, Oxford, p 199-204

Editorial responsibility: Jed Fuhrman,

Los Angelos, California, USA
Suttle CA, Chen F (1992) Mechanisms and rates of decay of marine viruses in seawater. Appl Environ Microbiol 58: 3721-3729

Weinbauer MG, Wilhelm SW, Suttle CA, Pledger RJ, Mitchell DL (1999) Sunlight-induced DNA damage and resistance in natural viral communities. Aquat Microb Ecol 17:111-120

Weinbauer MG, Brettar I, Hofle MG (2003) Lysogeny and virus-induced mortality of bacterioplankton in surface, deep and anoxic marine waters. Limnol Oceanogr 48: $1457-1465$

Wells LE (2006) Viral adaptations to life in the cold. PhD dissertation, University of Washington, Seattle

Wells LE, Deming JW (2006a) Modelled and measured dynamics of viruses in Arctic winter sea-ice brines. Environ Microbiol 8:1115-1121

Wells LE, Deming JW (2006b) Significance of bacterivory and viral lysis in bottom waters of Franklin Bay, Canadian Arctic, during winter. Aquat Microb Ecol 43:209-221

Wells LE, Deming JW (2006c) Characterization of a cold-active bacteriophage on two psychrophilic marine hosts. Aquat Microb Ecol 45:15-29

Wells LE, Cordray M, Bowerman S, Miller LA, Vincent WF, Deming JW (2006) Archaea in particle-rich waters of the Beaufort Shelf and Franklin Bay, Canadian Arctic: clues to an allochthonous origin? Limnol Oceanogr 51:47-59

Wiebe WJ, Liston J (1968) Isolation and characterization of a marine bacteriophage. Mar Biol 1:244-249

Wilhelm SW, Weinbauer MG, Suttle CA, Jeffrey WH (1998a) The role of sunlight in the removal and repair of viruses in the sea. Limnol Oceanogr 43:586-592

Wilhelm SW, Weinbauer MG, Suttle CA, Pledger RJ, Mitchell DL (1998b) Measurements of DNA damage and photoreactivation imply that most viruses in marine surface waters are infective. Aquat Microb Ecol 14:215-222

Whitman PA, Marshall RT (1971) Characterization of two psychrophilic Pseudomonas bacteriophages isolated from ground beef. Appl Microbiol 22:463-468

Wommack KE, Hill RT, Muller TA, Colwell RR (1996) Effects of sunlight on bacteriophage viability and structure. Appl Environ Microbiol 62:1336-1341

Submitted: December 21, 2005; Accepted: July 20, 2006

Proofs received from author(s): October 23, 2006 